Article

\title{
Pharmacological Evaluation of the Anticancer Activity of Extracts and Fractions of Lannea barteri Oliv. (Anacardiaceae) on Adherent Human Cancer Cell Lines
}

\author{
Florence N. Mbaoji ${ }^{1,2, *}$, Steven Behnisch-Cornwell ${ }^{2}$, Adaobi C. Ezike ${ }^{1}(\mathbb{D}$, \\ Chukwuemeka S. Nworu ${ }^{1}$ (D) and Patrick J. Bednarski ${ }^{2, *}$ \\ 1 Department of Pharmacology and Toxicology, Faculty of Pharmaceutical Sciences, University of Nigeria, \\ Nsukka, PMB 410001, Enugu State, Nigeria; adaobi.ezike@unn.edu.ng (A.C.E.); \\ chukwuemeka.nworu@unn.edu.ng (C.S.N.) \\ 2 Institute of Pharmacy, Pharmaceutical and Medicinal Chemistry, University of Greifswald, 17487 Greifswald, \\ Germany; steven.behnisch@uni-greifswald.de \\ * Correspondence: florence.mbaoji@unn.edu.ng (F.N.M.); bednarsk@uni-greifswald.de (P.J.B.); \\ Tel.: +2348065193858(F.N.M.); +4938344204883(P.J.B.)
}

Academic Editors: Luisa Tesoriere, Alessandro Attanzio and Riccardo Petrelli Received: 30 December 2019; Accepted: 7 February 2020; Published: 14 February 2020

check for updates

\begin{abstract}
In western Africa ethnomedicine, Lannea barteri Oliv. (Anacardiaceae) is believed to have activity against gastrointestinal, neurological and endocrine diseases. Previous studies on this plant have revealed antimicrobial, anticholinestrase, anticonvulsant, antioxidant and anti-inflammatory activities. However, the anticancer potential of L. barteri has not been studied to date. The aim of this study was to evaluate the anticancer potential of hot and cold extracts and silica gel column chromatographic fractions of L. barteri leaf and stem bark. The extracts and fractions were tested for anticancer activity by using the crystal violet cell proliferation assay on four adherent human carcinoma cell lines-5637 (bladder), KYSE 70 (oesophagus), SiSo (cervical) and HepG2 (hepatic). The inhibitory concentration $\left(\mathrm{IC}_{50}\right)$ of fractions $\mathrm{IH}, 1 \mathrm{I}, 2 \mathrm{E}$ and $2 \mathrm{~F}$ were: $3.75 \pm 1.33,3.88 \pm 2.15$, $0.53 \pm 0.41$, and $0.42 \pm 0.45 \mu \mathrm{g} / \mathrm{mL}$ against KYSE 70 and $1.04 \pm 0.94,2.69 \pm 1.17,2.38 \pm 3.64$, $2.17 \pm 1.92 \mu \mathrm{g} / \mathrm{mL}$ against SiSo cell lines respectively. Fraction $2 \mathrm{E}$ showed weak apoptotic activity at double the $\mathrm{IC}_{50}$ and some sign of cell cycle arrest in the $\mathrm{G} 2 / \mathrm{M}$ phase. Thus, phytoconstituents of L. barteri leaf and stem bark can inhibit the proliferation of cancer cell lines indicating the presence of possible anticancer agents in this plant.
\end{abstract}

Keywords: Lannea barteri; leaf; stem bark; adherent human carcinoma cell lines; 5637; KYSE 70; SiSo; HepG2

\section{Introduction}

Medicinal plants used in folk medicine are a rich source of compounds with anticancer activities. Studies of traditional medicine have resulted in pharmacological entities that have good efficacy and different mechanisms of action from the existing orthodox medicines. It is believed that phytoconstituents are good alternatives to conventional drugs used in the treatment of diseases because they are inexpensive and may have less adverse effects [1]. Despite the growing concern about these plant products due to their lack of standardization, they are in high demand by traditional care givers for the treatment of various diseases including cancer. Thus, there are growing research interests geared towards natural products for finding new drug entities from among the myriad of plant species in African forests that are largely untapped. These efforts have often been successful since many plant 
materials have been found to have numerous and diverse pharmacological activities. Lannea barteri is one of such plant that may be a source of anticancer agents.

L. barteri is a dioecious tree with a spreading crown; it can grow from 5-18 meters tall (Figure 1). The bole is usually straight and clear of branches for several meters. It can be up to $40 \mathrm{~cm}$ in diameter with a thick bark. Leaves are alternate, pinnately compound with 2-6 pairs of opposite leaflets and a terminal cone, rachis 10-25 cm long, leaflets shortly stalked. Flowers are unisexual, regular, pedicel up to $3 \mathrm{~mm}$ long, calyx-cupped shaped with lopes $1 \mathrm{~mm}$ long, ciliate, petals oblong yellowish with darker veins. Fruits are compressed cylindrical drupe 10-13 $\mathrm{mm} \times 7-8 \mathrm{~mm}$ glabrous, purplish red [2].

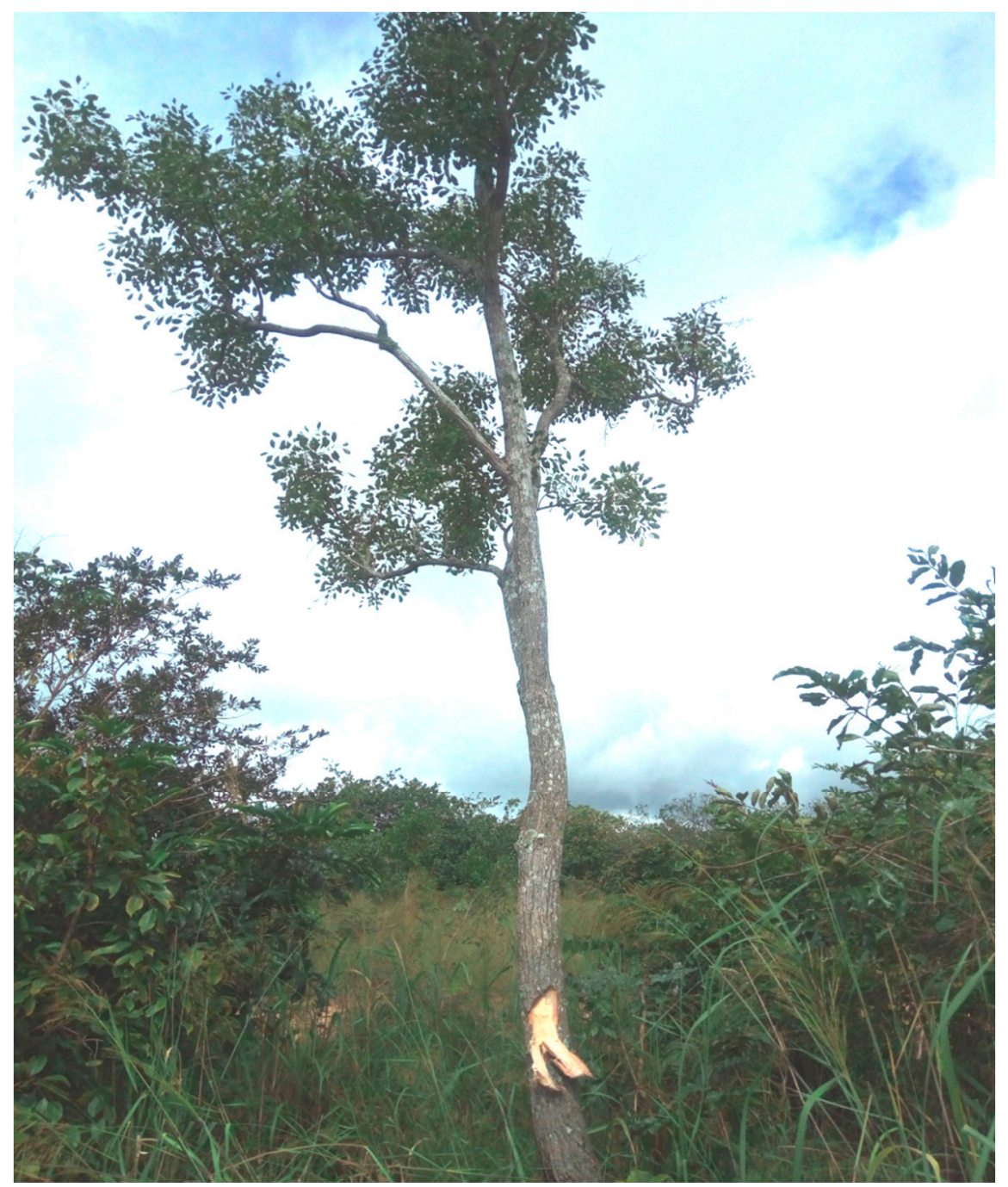

Figure 1. Lannea barteri tree growing in Nigeria used in sample collection.

Indeed L. barteri is widely used in western Africa in folk medicine. It is called sinsabega in Bimoba, mon in Dahomey Bassari, kuntunkuni in Ghana Akan-Asante, kuntunkurfi in Brong and in Ivory Coast Baule it is called kondro. It is known as faruhi in the northern part of Nigeria, and tiuko in Guinea [3]. L. barteri originates from East Guinea and is distributed in Ethiopia, Uganda, South of DR Congo, Nigeria, Mali, Burkina Faso, Ghana, Cote d' Ivoire and Burundi [4,5]. The bark is frequently used as a stomachic. A decoction of the root is drunk as a treatment for gastric pains, diarrhoea, oedema, paralysis, epilepsy and madness [4]. When combined with the bark of Lannea kerstingii, it is used as a vermifuge [4]. The bark is used externally to treat ulcers, sores and leprosy. The root decoction is taken to cure hernias. The root is ground, wrapped in the leaves of an unknown species, and applied as poultice on wounds. A leaf decoction is taken to cure haemorrhoids [6]. Phytochemical investigations 
on the stem bark and root of the plant have revealed the presence of saponins, coumarins, polyphenols, alkaloids, tannins, quinones, steroids, terpenoids, and flavonoids [7,8]. Previous works on the stem bark and root bark of L. barteri have revealed antimicrobial [7,8], anticholinesterase, DPPH radical scavenging [7], anticonvulsant [9] activities, and on leaf extract antioxidant, hepatoprotective [10], wound healing and anti-inflammatory activities [11]. Oxidative stress and chronic inflammatory response have deleterious effect on macromolecules; thus, they can trigger different types of cancers. Since the antioxidant and anti-inflammatory activities of this plant extract are good properties for cancer prevention, and considering the link between oxidation and chronic inflammation to the development of cancer, the need to explore the anticancer activity of this plant extract arose. The aim of this study was to evaluate the anticancer potential of hot and cold extracts and column chromatography fractions of leaf and stem bark of L. barteri on four adherent human carcinoma cell lines—5637 (bladder), KYSE 70 (oesophagus), SiSo (cervical) and HepG2 (hepatic) as well as the toxic effect of the extracts on Artemia salina larva.

\section{Results}

\subsection{Yield of Extracts and Fractions}

The extraction processes yielded hot $(\mathrm{h})$ and cold $(\mathrm{c})$ dichloromethane (DCM) (DLEh, DLEc, DSbEh, DSbEc), methanol (MLEh, MLEc, MSbEh, MSbEc) and water (WLEh, WLEc, WSbEh, WSbEc) extracts. The yields of the various extracts are shown in Table 1. The thin layer chromatography (TLC) of DLEc and DSbEc gave different spots with varying retention factors (Table 2). Similarly, fractionation of the DLEc and DSbEc by silica gel column chromatography yielded 11 fractions (1A-1K) from DLEc and 10 fractions (2A-2J) from DSbEc (Table 3).

\subsection{Phytochemical Constituents of Extracts and Most Active Chromatography Fractions}

Phytochemical analysis on the DLEc and DSbEc gave positive reactions for terpenoids and steroids, respectively.

Table 1. Yield of L. barteri leaves and stem bark extracts.

\begin{tabular}{ccc}
\hline Extract & \multicolumn{2}{c}{ Yield } \\
\hline & $\mathbf{m g}$ & $\mathbf{\%}$ \\
\hline DLEc & 40.1 & 1.86 \\
DSbEc & 46.1 & 1.15 \\
DLEh & 235.2 & 2.35 \\
DSbEh & 216.1 & 2.37 \\
MLEc & 195.0 & 9.75 \\
MSbEc & 78.5 & 3.93 \\
MLEh & 748.7 & 17.49 \\
MSbEh & 912.0 & 10.03 \\
WLEc & 90.4 & 4.52 \\
WSbEc & 47.0 & 2.35 \\
WLEh & 718.8 & 7.17 \\
WSbEh & 227.3 & 2.27
\end{tabular}

DLEc — cold dichloromethane (DCM) leaf extract, DSbEc—cold DCM stem bark extract, DLEh—hot DCM leaf extract, DSbEh—hot DCM stem bark extract, MLEc — cold methanol leaf extract, MSbEc—cold methanol stem bark extract, MLEh — hot methanol leaf extract, MSbEh—hot methanol stem bark extract, WLEc—cold water leaf extract, WSbEc — cold water stem bark extract, WLEh—hot water leaf extract and WSbEh—hot water stem bark extract. 
Table 2. TLC retention factor $\left(R_{f}\right)$ values of the most active extracts.

\begin{tabular}{ccc}
\hline $\begin{array}{c}\text { Solvent Ratio } \\
\text { (n-hexane: ethyl acetate) }\end{array}$ & DLEc & DSbEc \\
\hline & \multicolumn{2}{c}{$\mathbf{R}_{\mathbf{f}}$} \\
\cline { 2 - 3 }$: 1$ & 0.25 & 0.30 \\
$8: 2$ & 0.38 & 0.32 \\
$7: 3$ & 0.47 & 0.50 \\
$6: 4$ & 0.50 & 0.55 \\
$5: 5$ & 0.68 & 0.70 \\
$4: 6$ & 0.44 & 0.38 \\
$3: 7$ & 0.40 & 0.30 \\
$2: 8$ & 0.26 & 0.28 \\
$1: 9$ & 0.22 & 0.25 \\
\hline DLEc = cold DCM leaf extract; DSbEc $=$ cold DCM stem bark extract.
\end{tabular}

Table 3. Yield of fractions from chromatography of cold DCM leaf and stem bark extracts.

\begin{tabular}{cccc}
\hline Fractions & $\begin{array}{c}\text { Pooled } \\
\text { Samples }\end{array}$ & Weight $(\mathbf{m g})$ & $\begin{array}{c}\text { Yield } \\
\text { (\%) }\end{array}$ \\
\hline 1A & $8-13$ & 3.30 & 0.66 \\
1B & $14-20$ & 15.50 & 3.10 \\
1C & $21-28$ & 27.80 & 5.56 \\
1D & $29-37$ & 13.40 & 2.68 \\
1E & $38-42$ & 113.70 & 22.74 \\
1F & $43-47$ & 31.70 & 6.34 \\
1G & $48-56$ & 13.60 & 2.72 \\
1H & $57-85$ & 14.90 & 2.98 \\
1I & $86-102$ & 7.80 & 1.56 \\
1J & $103-187$ & 41.00 & 8.20 \\
1K & $188-192$ & 39.40 & 7.00 \\
\hline & & & \\
2A & $1-7$ & 8.20 & 1.64 \\
2 B & $8-24$ & 9.30 & 1.86 \\
2 C & $25-40$ & 13.00 & 2.60 \\
2 D & $41-44$ & 29.60 & 5.92 \\
2 E & $45-51$ & 48.20 & 9.64 \\
2 F & $52-61$ & 69.80 & 13.96 \\
2 G & $62-77$ & 59.50 & 11.90 \\
2 H & $78-105$ & 54.10 & 10.82 \\
2 I & $106-109$ & 84.00 & 16.80 \\
2 J & $110-140$ & 8.80 & 1.76 \\
\hline (1A-K) and (2A-J) represent fractions from DLEc and DSbEc respectively.
\end{tabular}

2.3. The RP-HPLC Chromatograms of the Active Fractions from the Cold DCM Extracts of Leaf (1E-1J) and Stem Bark (2D-2I)

The chromatograms of the active fractions from the cold DCM extracts of leaf (1E-1J) and stem bark (2D-2I) revealed absorption peaks (Au) of different heights at varying wavelengths between (210-600 nm) and retention times. The chromatogram of fraction 1E revealed five prominent peaks between retention times 24 and $32 \mathrm{~min}$ (Figure S1). Fraction 1F gave eight peaks with two prominent peaks occurring at 29.20 and $31.01 \mathrm{~min}$ (Figure S2). Fraction $1 \mathrm{G}$ gave a total of six peaks with three major sharp peaks at 28.72, 29.19 and 30.96 min retention times (Figure S3). Fraction $1 \mathrm{H}$ gave nine major peaks with the first three peaks well separated from one another at retention times of 13.25, 14.83 and $16.61 \mathrm{~min}$; also, the eighth peak was very sharp at retention time of $39.37 \mathrm{~min}$ (Figure S4). Fraction 1I had two major peaks occurring at retention times of 28.72 and 30.64 and clusters of other peaks (Figure S5). Fractions 1J and 1K had similar peaks with two major peaks occurring at 20.73/20.64 min and 30.73/30.56 min respectively and with clusters of other minor peaks (Figures S6 and S7). 
Fraction 2D gave three peaks with one sharp peak which eluted at $24.75 \mathrm{~min}$ (Figure S8). Fraction 2E gave five peaks, two sharp peaks and other broad peaks (Figure S9). Fraction 2F gave three prominent and well-separated sharp peaks at 18.96, 23.73 and 31.87 min with two additional minor peaks (Figure S10). Fraction 2G gave seven peaks some of which were well separated (Figure S11) while fraction $\mathrm{H}$ gave two broad peaks and one sharp peak which occurred at 27.41 min (Figure S12). Fraction 2I gave only one broad peak that eluted at $14.67 \mathrm{~min}$ (Figure S13).

\subsection{Effect of Extracts of on 5637, KYSE 70 and SiSo Cancer Cell Lines Proliferation in Primary Screening}

DLEh and DSbEh inhibited the proliferation of all the cancer cell lines while the MLEh, MSbEh, WLEh and WSbEh showed no growth inhibition. The (T/C) corr. (\%) values of DLEh, MLEh, MSbEh, WLEh and WSbEh for the various cancer cell lines are shown in Table 4.

DLEc and DSbEc extracts inhibited the proliferation of all the cancer cell lines tested while MLEc and MSbEc inhibited 5637 and SiSo cell lines only. The WLEc and WSbEc did not inhibit the proliferation of any of the cancer cell lines. The $\mathrm{T} / \mathrm{C}_{\text {corr }} .(\%)$ values for the extracts that had activity are shown in Table 4.

The order of antiproliferation activity of DLEc and DSbEc on the cell lines was SiSo $>$ KYSE $70>5637$.

The extracts with $\mathrm{T} / \mathrm{C}_{\text {corr }}$. values less than $50 \%$ were thus selected for secondary screening.

Table 4. Antiproliferative activity T/C corr. (\%) of extracts $(50 \mu \mathrm{g} / \mathrm{mL})$ on $5637, \mathrm{KYSE} 70$ and SiSo cell lines in primary screening.

\begin{tabular}{cccc}
\hline & Extract & \multicolumn{2}{c}{ Cell Line } \\
\hline & 5637 & KYSE 70 & SiSo \\
\hline & & T/C corr. (\%) \\
DLEc & 14.76 & 5.83 & 4.62 \\
DSbEc & 7.82 & 3.03 & 2.56 \\
DLEh & 2.01 & 5.18 & 4.21 \\
DSbEh & -3.12 & 4.63 & 2.67 \\
MLEc & 1.77 & $>50$ & 20.95 \\
MSbEc & 3.64 & $>50$ & 24.33 \\
MLEh & $>50$ & $>50$ & $>50$ \\
MSbEh & $>50$ & $>50$ & $>50$ \\
WLEc & $>50$ & $>50$ & $>50$ \\
WSbEc & $>50$ & $>50$ & $>50$ \\
WLEh & $>50$ & $>50$ & $>50$ \\
WSbEh & $>50$ & $>50$ &
\end{tabular}

Stock solution concentration $=50 \mu \mathrm{g} / \mathrm{mL}$ DMSO, $n=2$; DLEc-cold DCM leaf extract, DSbEc-cold DCM stem bark extract, DLEh—hot DCM leaf extract, DSbEh-hot DCM stem bark extract, MLEc — cold methanol leaf extract, MSbEc - cold methanol stem bark extract, MLEh-hot methanol leaf extract, MSbEh-hot methanol stem bark extract, WLEc - cold water leaf extract, WSbEc - cold water stem bark extract, WLEh-hot water leaf extract and WSbEh-hot water stem bark extract; $\mathrm{T} / \mathrm{C}_{\text {corr. }}$ - - treated versus control corrected.

\subsection{Effects of Extracts on KYSE 70 and SiSo Cell Lines in Secondary Screening}

The $\mathrm{IC}_{50}$ values of the hot extracts (DLEh, DSbEh. MLEh and MSbEh) against the KYSE 70 and SiSo cell lines are shown in Table 5. The DSbEh inhibited growth of both cell lines more than the DLEh. The MLEh inhibited only the SiSo cell line while the MSbEh inhibited the growth of none of the cancer cell lines (Table 5).

The growth inhibitory effect of the DSbEc on the KYSE 70 and SiSo were significantly $(p<0.05)$ higher than that of DLEc. The MLEc significantly $(p<0.05)$ inhibited the SiSo cell line more than the MSbEc (Table 5).

The comparison of the cell proliferative inhibitory activity of the hot and cold DCM extracts on the KYSE 70 cell line showed no significant difference between DLEh and DLEc, and between DLEh, DLEc and DSbEh; but there was significant $(p<0.05)$ difference between DLEh, DLEc and DSbEc with DSbEc showing the highest inhibitory activity (Figure 2A). There was no significant difference in the 
growth inhibitory activities of SiSo cancer cell line by the leaf and stem bark extracted with hot and cold DCM (Figure 2B).

Table 5. IC Fo $_{0}$ of extracts on KYSE 70 and SiSo cell lines in secondary screening.

\begin{tabular}{ccc}
\hline Extract & \multicolumn{2}{c}{ Cell Line } \\
\hline \multicolumn{3}{c}{ KYSE 70 } \\
\hline \multicolumn{2}{c}{ IC $_{\mathbf{5 0}}(\boldsymbol{\mu} \mathrm{g} / \mathrm{mL})$} \\
DLEc & $11.03 \pm 2.68$ & $12.06 \pm 8.39$ \\
DSbEc & $2.26 \pm 0.92$ & $6.37 \pm 2.15$ \\
DLEh & $12.23 \pm 3.12$ & $10.68 \pm 2.36$ \\
DSbEh & $5.28 \pm 3.43$ & $5.62 \pm 3.00$ \\
MLEc & $>50$ & $11.01 \pm 4.04$ \\
MSbEc & $>50$ & $23.85 \pm 9.41$ \\
MLEh & $>50$ & $20.93 \pm 4.09$ \\
MSbEh & $>50$ & $>50$ \\
\hline
\end{tabular}

Stock solution concentration = $50 \mu \mathrm{g} / \mathrm{mL}$ DMSO for DLEh, DSbEh, MLEc, MSbEc, MLEc and MSbEh, $25 \mu \mathrm{g} / \mathrm{mL}$ DMSO for DLEc and DSbEc. $n=3$; DLEc — cold DCM leaf extract, DSbEc — cold DCM stem bark extract, DLEh-hot DCM leaf extract, DSbEh—hot DCM stem bark extract, MLEc—cold methanol leaf extract, MSbEc — cold methanol stem bark extract, MLEh—hot methanol leaf extract, MSbEh—hot methanol stem bark extract, WLEc — cold water leaf extract, WSbEc — cold water stem bark extract, WLEh—hot water leaf extract and WSbEh—hot water stem bark extract.

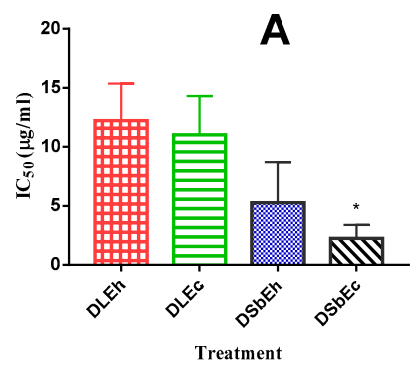

$* \mathrm{p}<0.05$ compared to DLEh and DLEc

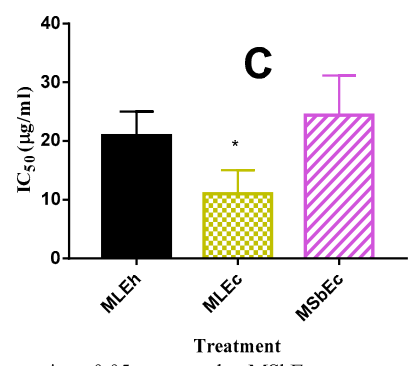

$* \mathrm{p}<0.05$ compared to MSbEc

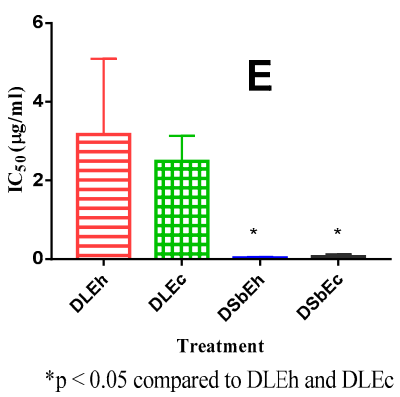

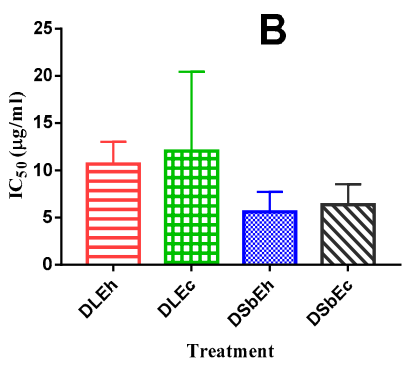

No significant difference between treatments.

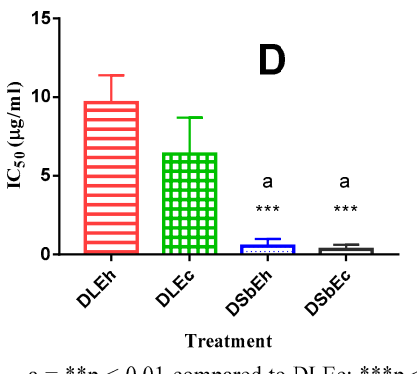

$\mathrm{a}=* * \mathrm{p}<0.01$ compared to DLEc; $* * * \mathrm{p}<$ 0.001 compared to DLEh

Figure 2. Comparison of $\mathrm{IC}_{50}$ of hot and cold DCM and methanol extracts of leaf and stem bark against KYSE 70, SiSo, HepG2 and 5637 cell lines. $(\mathbf{A})=$ KYSE 70 cell line, $(\mathbf{B}, \mathbf{C})=$ SiSo cell line, $(\mathbf{D})=$ HepG2 cell line, $(\mathbf{E})=5637$ cell line. Values are mean \pm SEM $(n=3)$ one-way ANOVA. (Tukey's multiple comparisons test). DLEc — cold DCM leaf extract, DSbEh—hot DCM stem bark extract, MLEc—cold methanol leaf extract, MSbEc—cold methanol stem bark extract, MLEh—hot methanol leaf extract. 
There was no significant difference in the growth inhibitory activity of MLEh, MLEc and MSbEc on SiSo cell line. MLEc produced significantly $(p<0.05)$ higher inhibitory activity on SiSo cancer cell line when compared to MSbEc (Figure 2C).

On the HepG2 cancer cell line, both the hot and cold DCM extracts of the leaf and stem bark inhibited the proliferation of this cell line (Figure 2D). DSbEh and DSbEc significantly $(p<0.001)$ inhibited the proliferation of HepG2 cancer cell line. When compared, DLEh and DLEc did not produce as much inhibition of HepG2 cancer cell line proliferation as DSbEh and DSbEc. Their IC 50 values of the inhibition of the various cancer cells proliferations are shown in shown in Figure 2D.

The cold and hot DCM leaf and stem bark extracts inhibited the proliferation of 5637 with lower $\mathrm{IC}_{50}$ values (Figure 2E). The inhibitory activities against 5637 were significantly $(p<0.05)$ higher with DSbEh and DSbEc compared to DLEh and DLEc (Figure 2E).

2.6. Effect of Column Chromatography Fractions of DLEc (fractions $1 A-K$ ) and DSbEc (fractions 2A-I) on 5637, KYSE 70, SiSo and HepG2 Cell Lines Proliferation in Primary Screening

After screening the various extracts for anticancer activity, those extracts with biological activity (e.g., DLEc, DSbEc) were subject to silica gel column chromatography and the collected fractions again screened for anticancer activity. The results showed that fractions $1 \mathrm{E}$ and $2 \mathrm{~F}$ produced a higher inhibitory effect on the proliferation of 5637 of cell lines than the other fractions tested (Table 6). Fractions $1 \mathrm{H}$ and $2 \mathrm{E}$ produced remarkable proliferation inhibition against KYSE 70 cell line (Table 6); fractions $1 \mathrm{D}$ and $2 \mathrm{E}$ inhibited the proliferation of SiSo cell line to a greater extent compared to the inhibition produced by other fractions (Table 6) while fractions $1 \mathrm{H}, 2 \mathrm{D}$ and $2 \mathrm{H}$ inhibited the proliferation of HepG2 cell line largely compared to other fractions (Table 6).

Table 6. Antiproliferative activity as $\mathrm{T} / \mathrm{C}$ corr. $(\%)$ of fractions $(50 \mu \mathrm{g} / \mathrm{mL})$ on $5637, \mathrm{KYSE} 70$, SiSo and HepG2 cell lines.

\begin{tabular}{ccccc}
\hline \multicolumn{5}{c}{ Fraction } \\
\multicolumn{5}{c}{ Cell line } \\
\hline & 5637 & KYSE 70 & SiSo & HepG2 \\
\cline { 2 - 5 } 1A & 33.67 & T/C corr. (\%) \\
1B & 3.06 & 62.12 & 100.00 & 20.58 \\
1C & 3.06 & 69.29 & 116.02 & 44.33 \\
1D & -9.18 & 61.57 & -10.50 & 37.99 \\
1E & -11.22 & -0.22 & -4.18 & -7.39 \\
1F & -1.02 & -2.22 & -4.50 & -10.95 \\
1G & -9.66 & -2.95 & -6.75 & -12.40 \\
1H & -6.90 & -4.15 & -6.59 & 14.25 \\
1I & -7.38 & -4.04 & -6.27 & 14.12 \\
1J & -8.18 & -3.82 & -6.11 & 14.38 \\
1K & 15.54 & -4.42 & -2.73 & 10.55 \\
\hline 2A & 22.94 & 71.51 & 23.79 & 83.51 \\
2B & -14.94 & 51.64 & 21.57 & 48.15 \\
2C & -16.91 & 12.01 & 6.11 & -1.58 \\
2D & -16.21 & -4.91 & -0.07 & -14.64 \\
2E & -15.01 & -5.13 & -7.24 & -14.51 \\
2F & -17.01 & -4.80 & -7.07 & -14.51 \\
2G & -13.91 & -5.02 & -6.43 & -13.98 \\
2H & -8.91 & -4.80 & -6.01 & -14.64 \\
2I & -13.17 & -4.04 & -5.95 & -11.21 \\
2J & -9.34 & 62.55 & 22.51 & 10.82 \\
\hline
\end{tabular}


2.7. Effect of Column Chromatography Fractions of DLEc (Fractions 1E-1K) and DSbEc (Fractions 2D-2I) on KYSE 70 and SiSo and HepG2 Cell Lines Proliferation in Secondary Screening

Secondary screening was done on the various active fractions to estimate $\mathrm{IC}_{50}$ values. The $\mathrm{IC}_{50}$ value of fractions $1 \mathrm{H}(3.75 \mu \mathrm{g} / \mathrm{mL})$ and $1 \mathrm{I}(3.88 \mu \mathrm{g} / \mathrm{mL})$ were significantly $(p<0.001)$ lower than that of fraction $1 \mathrm{~K}(20.21 \mu \mathrm{g} / \mathrm{mL})$ when inhibition of cell proliferation produced by all the fractions against KYSE 70 cell line were compared (Figure $3 \mathrm{~A})$. Similarly, the $\mathrm{IC}_{50}$ values of fractions $1 \mathrm{G}(9.77 \mu \mathrm{g} / \mathrm{mL})$ and $1 \mathrm{~J}(8.22 \mu \mathrm{g} / \mathrm{mL})$ were significantly lower than that of fraction $1 \mathrm{~K}$ while the $\mathrm{IC}_{50}$ values of fractions $1 \mathrm{E}$ $(10.37 \mu \mathrm{g} / \mathrm{mL})$ and IF $(11.89 \mu \mathrm{g} / \mathrm{mL})$ were lower than that of fraction $\mathrm{K}$ but not significantly (Figure 3A).

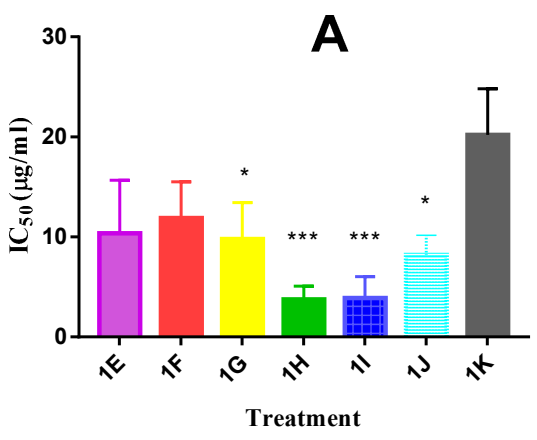

IC $_{50}$ values of fractions $1 \mathrm{E}-1 \mathrm{~K}$ from cold DCM extract of leaf on KYSE 70 cell line. $\quad{ }^{*} p<0.05, * * * p<0.001$ compared to $1 \mathrm{~K}$.

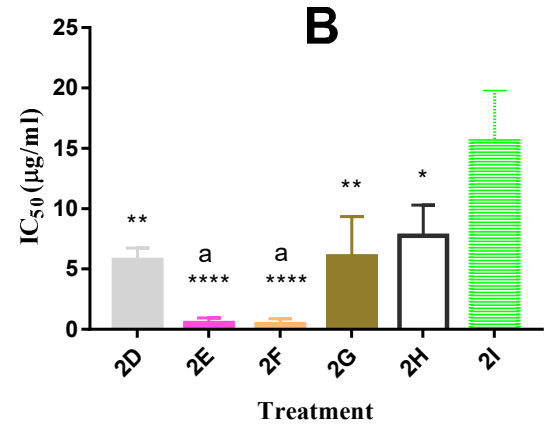

IC $_{50}$ values of fractions 2D - 2I from cold DCM extract of stem bark against KYSE 70 cell line. $\quad * \mathrm{p}<0.05, * * \mathrm{p}<$ $0.01,{ }^{* * * *} \mathrm{p}<0.0001$ compared to $2 \mathrm{I}$, and at $\mathrm{a}=*_{\mathrm{p}}<0.05$ compared to $2 \mathrm{H}$

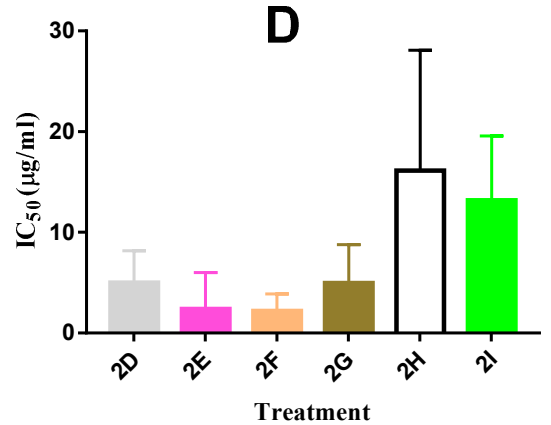

IC $_{50}$ values of fractions 2D - 2I from cold DCM extract of stem bark against SiSo cell line. Values are not significant between treatments

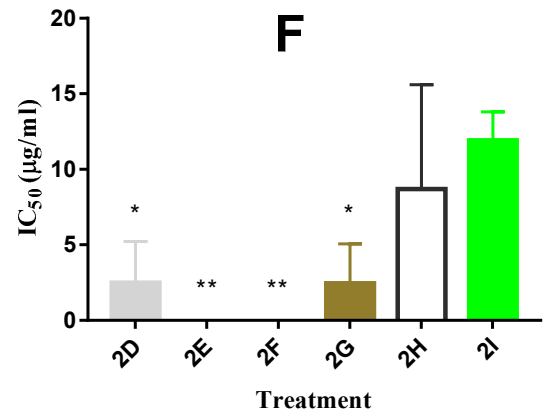

$\mathrm{IC}_{50}$ of values fractions $2 \mathrm{D}$ - 2I from cold DCM extract of stem bark against HepG 2 cell line. ${ }^{*} \mathrm{p}<0.05$ and ${ }^{* *} \mathrm{p}<$ 0.01 compared to $2 \mathrm{I}$.

$\mathrm{IC}_{50}$ values of fractions $1 \mathrm{E}-1 \mathrm{~K}$ from cold $\mathrm{DCM}$
extract leaf against HepG2 cell line. $\quad \mathrm{a}={ }^{*} \mathrm{p}<0$ compared to $1 \mathrm{E},{ }^{* *} \mathrm{p}<0.01$ and ${ }^{* * *} \mathrm{p}<0.001$ compared to $1 \mathrm{~K}$

Figure 3. $\mathrm{IC}_{50}$ values of fractions $1 \mathrm{E}-1 \mathrm{~K}$ and $2 \mathrm{D}-2 \mathrm{I}$ from DLEc and DSbEc respectively against the cell lines. $(\mathbf{A}, \mathbf{B})=$ KYSE 70 cell line, $(\mathbf{C}, \mathbf{D})=$ SiSo cell line and $(\mathbf{E}, \mathbf{F})=$ HepG2 cell line. Values are mean \pm SEM $(n=3)$ one-way ANOVA (Tukey's multiple comparisons test). 
The $\mathrm{IC}_{50}$ values in $\mu \mathrm{g} / \mathrm{mL}$ for these fractions were $5.77(2 \mathrm{D}), 0.53(2 \mathrm{E}), 0.42(2 \mathrm{~F}), 6.05(2 \mathrm{G}), 7.76(2 \mathrm{H})$ and $15.58(2 \mathrm{I})$. There was significant $(p<0.0001)$ difference between the $\mathrm{IC}_{50}$ of fractions $2 \mathrm{E}$ and $2 \mathrm{~F}$ compared to fraction 2I on their inhibition against KYSE 70 (Figure 3B). There was significant $(p<0.01)$ difference in the $\mathrm{IC}_{50}$ values of fractions $2 \mathrm{D}$ and $2 \mathrm{G}$ in comparison to that of fraction $2 \mathrm{I}$ while the $\mathrm{IC}_{50}$ of fraction $2 \mathrm{~F}$ significantly $(p<0.05)$ differed from that of fraction $2 \mathrm{H}$ just as the $\mathrm{IC}_{50}$ of fraction $2 \mathrm{H}$ significantly $(p<0.05)$ differed from that of fraction 2I (Figure 3B).

The leaf fractions inhibited the proliferation of SiSo cell line to varying extent. Significant $(p<0.05)$ inhibition of SiSo cell line proliferation were recorded with fractions 1F, 1H, 1I, 1J and $(p<0.01)$ with fraction $1 \mathrm{H}$ compared to fraction $1 \mathrm{~K}$ (Figure $3 \mathrm{C}$ ).

There was no significant difference in the $\mathrm{IC}_{50}$ values of the stem bark fractions that inhibited the proliferation of SiSo cell line when compared with the various treatments (Figure 3D).

The proliferative inhibitory activity of fractions $1 \mathrm{H}$ and $1 \mathrm{I}$ against HepG2 cell line were significant $(p<0.05$ and $p<0.001)$ when compared to fractions $1 \mathrm{E}$ and IK respectively; they had the lowest $\mathrm{IC}_{50}$ values of 0.25 and $0.30 \mu \mathrm{g} / \mathrm{mL}$ respectively when all the treatment groups were compared (Figure $3 \mathrm{E}$ ).

Fractions $2 \mathrm{E}$ and $2 \mathrm{~F}$ had the lowest $\mathrm{IC}_{50}$ values $\left(8.8 \times 10^{-4}\right.$ and $2.06 \times 10^{-4} \mu \mathrm{g} / \mathrm{mL}$, respectively) when compared with other fractions (2D, 2G, 2H, and 2I) against HepG2. The inhibitory effect of the $2 \mathrm{E}$ and $2 \mathrm{~F}$ fractions against the proliferation of HepG2 cell line were significant $(p<0.01)$ compared to fraction 2I (Figure 3F).

\subsection{Effect of Column Chromatography Fractions 1H, 1I 2E, 2F on Apoptosis Induction in SiSo Cancer Cell Line}

The percentage of apoptotic cells induced by the fractions and DMSO at $\mathrm{IC}_{50}$ value after $24 \mathrm{~h}$ and $48 \mathrm{~h}$ incubation periods respectively were $22.34 \%, 15.51 \%$ (DMSO), $19.9 \%, 16.38 \%(1 \mathrm{H}), 18.52 \%, 11.58 \%$ (1I), 31.09\%, $11.74 \%$ (2E), 30.87\% and 15.30\% (2F) (Figure 4). At concentrations doubled the $\mathrm{IC}_{50}$ values, the percentage of apoptotic cells induced by the fractions and DMSO at $24 \mathrm{~h}$ and $48 \mathrm{~h}$ incubation periods were $20.25 \%, 16.79 \%$ (DMSO), 31.16\%, 14.19\% (1H), 19.95\%, and $17.25 \%(1 \mathrm{I}), 47.07 \%, 34.00 \%(2 \mathrm{E})$, $27.85 \%$ and $25.83 \%(2 \mathrm{~F})$ respectively. From this result, fraction $2 \mathrm{E}$ gave the highest fractions $(47.07 \%$ and $34.00 \%$ ) of apoptotic cells at doubled the $\mathrm{IC}_{50}$ concentration after $24 \mathrm{~h}$ and $48 \mathrm{~h}$ incubation periods, respectively, compared with other fractions and control. Meanwhile, the leaf fractions especially fraction 1 I had the highest number $(0.68$ and $1.22 \%)$ of necrotic cells than the stem bark fractions at doubled the $\mathrm{IC}_{50}$ concentration after those incubation periods.

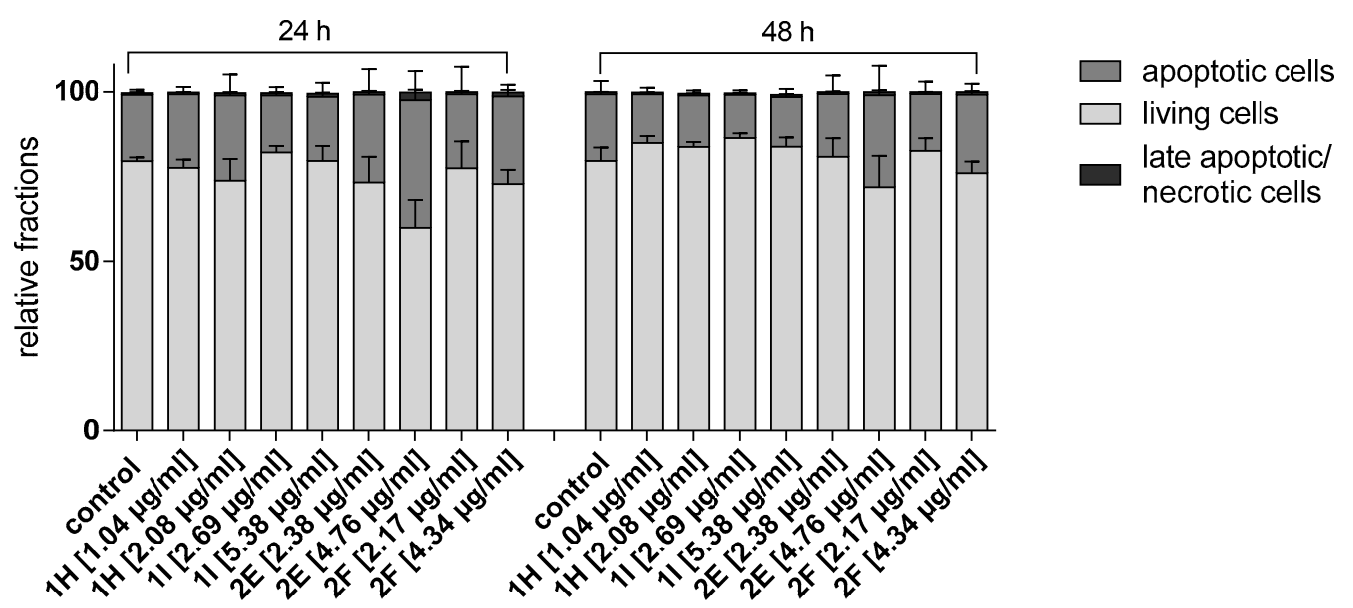

Figure 4. Effect of column chromatography fractions $1 \mathrm{H}, 1 \mathrm{I} 2 \mathrm{E}, 2 \mathrm{~F}$ (at $\mathrm{IC}_{50}$ concentration and doubled the $\mathrm{IC}_{50}$ concentration) on induction of apoptosis in SiSo cancer cell line after 24 and $48 \mathrm{~h}$ incubation periods.

\subsection{Effect of Fractions 1H, 1I 2E, 2F on Cell Cycle Progression in SiSo Cancer Cell Line}

In the cell cycle measurement, there was a non-significant reduction in the population of cells $(50.39 \%)$ in the G1/G0 phase with concomitant increase in the population of cells accumulated in S 
$(24.78 \%)$ and $\mathrm{G} 2 / \mathrm{M}(20.04 \%)$ phases especially at doubled the $\mathrm{IC}_{50}$ concentration of fraction $2 \mathrm{E}$ at $48 \mathrm{~h}$ incubation period compared to control (Figures 5 and 6). Fraction $1 \mathrm{H}$ accumulated the highest percentage (21.28\%) of cell population at G2/M phase followed by fraction 1I (20.47\%) at doubled the $\mathrm{IC}_{50}$ value after $24 \mathrm{~h}$ incubation period eventhough these changes were not significant (Figures 5 and 6 ).

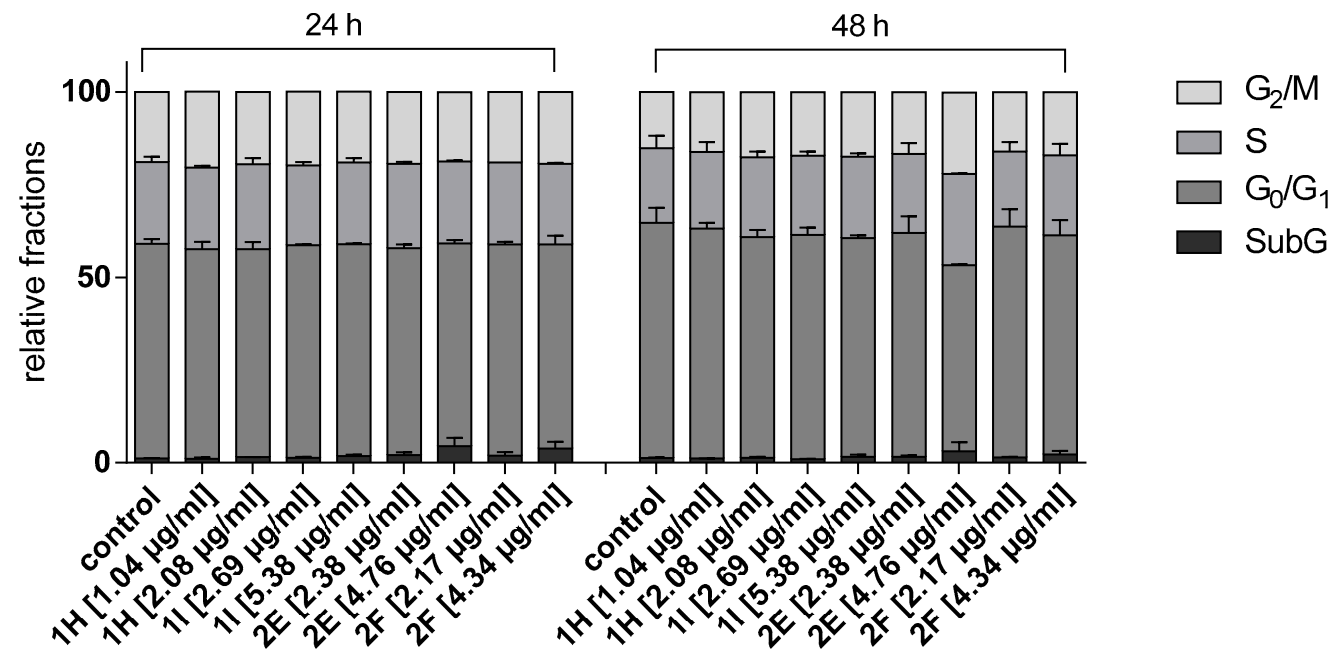

Figure 5. Effect of column chromatography fractions 1H, 1I 2E, 2F on cell cycle in SiSo cancer cell line.

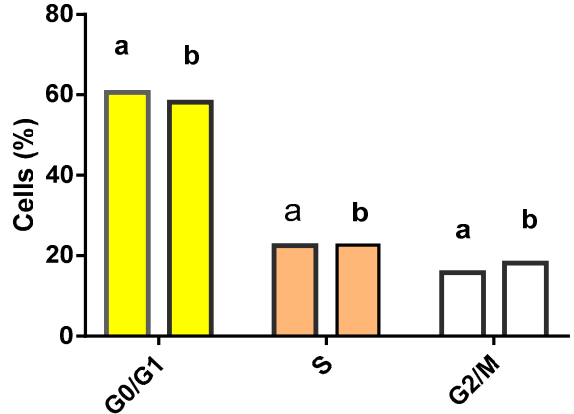

$a=$ DMSO

b $=$ Fraction $1 \mathrm{H}$

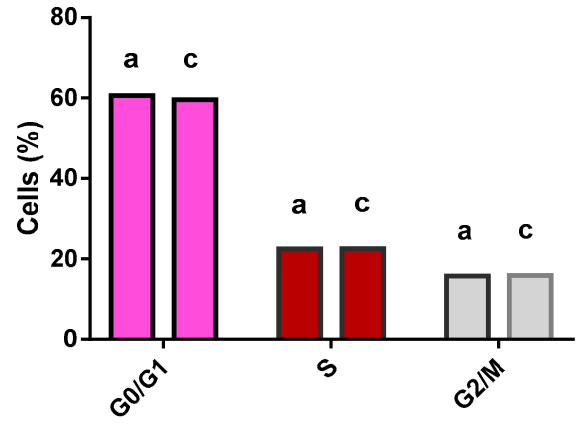

Cell cycle phases

$\mathrm{a}=$ DMSO

$c=$ Fraction 1 I

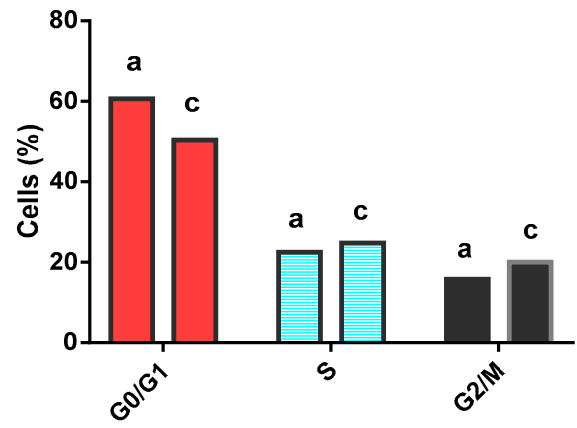

Cell cycle phases

$\mathrm{a}=\mathrm{DMSO}$

$c=$ Fraction $2 E$

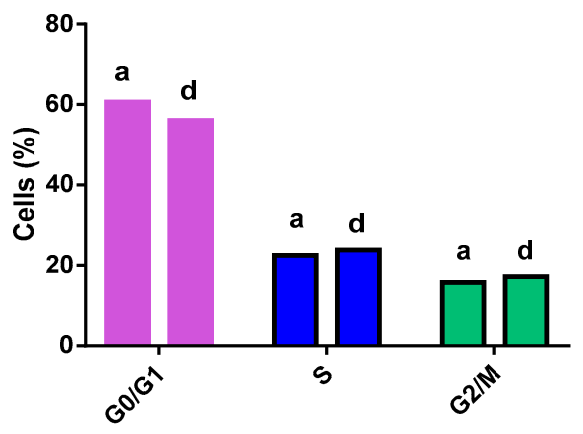

$\mathrm{a}=$ DMSO Cell cycle phases

$d=$ Fraction $2 F$

Figure 6. Effect of fractions column chromatography $1 \mathrm{H}, 1 \mathrm{I}, 2 \mathrm{E}$, and $2 \mathrm{~F}$ at doubled the $\mathrm{IC}_{50}$ concentration on cell cycle progression in SiSo cancer cell line after $48 \mathrm{~h}$ incubation. 


\subsection{Toxic effect of Extracts on Brine Shrimp}

To test for general toxicity of the extracts in vivo, the brine shrimp assay was used. In this assay, the lethal concentration at $50 \%$ of the population $\left(\mathrm{LC}_{50}\right)$ of the DLEc was found to be $5649.20 \mu \mathrm{g} / \mathrm{mL}$ while the extrapolated effective concentration was $564.92 \mu \mathrm{g} / \mathrm{mL}$. However, the LC 50 of DSbEc was $124.78 \mu \mathrm{g} / \mathrm{mL}$ while the $\mathrm{EC}_{50}$ was $12.48 \mu \mathrm{g} / \mathrm{mL}$. At $1000 \mu \mathrm{g} / \mathrm{mL}$, the percentage death was high $(66.7 \%)$ with DSbEc and low (13.3\%) with DLEc. The calculated therapeutic index (TI) for both extracts was 9.99 (Table 7).

Table 7. Toxic effect of extracts on brine shrimp.

\begin{tabular}{ccccc}
\hline Treatment & $\begin{array}{c}\text { Dose } \\
(\mu \mathrm{g} / \mathbf{m L})\end{array}$ & Alive & Dead & $\begin{array}{c}\text { Dead } \\
(\mathbf{\%})\end{array}$ \\
\hline DLEc & 10 & 29 & 1 & 3.3 \\
& 100 & 25 & 5 & 16.7 \\
& 1000 & 26 & 4 & 13.3 \\
\hline $\mathbf{1 0 \% \text { Tween } \mathbf { 8 0 }}$ & - & 30 & - & 0 \\
\hline DSbEc & 10 & 17 & 13 & 43.0 \\
& 100 & 11 & 19 & 63.3 \\
& 1000 & 10 & 20 & 66.7 \\
\hline
\end{tabular}

The estimated $\mathrm{LC}_{50}$ were $5649.20 \mu \mathrm{g} / \mathrm{mL}$ (DLEc) and $124.78 \mu \mathrm{g} / \mathrm{mL}$ (DSbEc); EC 50 were $564.92 \mu \mathrm{g} / \mathrm{mL}$ (DLEc) and $12.48 \mu \mathrm{g} / \mathrm{mL}$ (DSbEc) and therapeutic index (TI) was 9.99 for both. $\mathrm{LC}_{50}$ and $\mathrm{EC}_{50}$-lethal and effective concentrations at $50 \%$ population respectively, DLEc — cold DCM leaf extract, DSbEc-cold DCM stem bark extract, $n=30$.

\section{Discussion}

Cancer is a life-threatening and difficult-to-manage disease that ultimately overwhelms the entire bodily functions of the patient. This disease requires a multi-disciplinary approach to identify new pharmacological entities that will result in success and give strong and positive hope to the patient and the care giver. Some cancers can be cured completely when detected early either with chemotherapeutic agents, surgery, ionization therapy or a combination of two or more of these treatment options. Over the years, researchers have searched for new lead pharmacological compounds either from plants or other biological products that can be better than the existing drugs in terms of efficacy and safety. Certain plants have been investigated for their anticancer potentials and some of the plant materials have been found effective as anticancer agents. One such plant that interested us is Lannea barteri, a plant native to some African countries. This study investigated the anticancer potential of L. barteri leaf and stem bark extracts and fractions on four adherent human cancer cell lines: KYSE 70, SiSo, 5637 and HepG2 by using the crystal violet cell proliferation assay as a bioactivity guide [12]. Furthermore, the cytotoxic effect of DLEc and DSbEc on brine shrimp and the mechanism of anticancer activity of the fractions were studied. The phytoconstituents - terpenoids and steroids were present in DLEc and DSbEc, respectively.

Proliferation in cells is favored when there is phosphorylation of specific regulatory proteins by cyclin-dependent kinases, the engine that makes the cell cycle run [13]. Adherent cells detach from cell culture plate during cell death and this characteristic could be used for the indirect quantification of cell death and to find differences in proliferation upon stimulation with death-inducing agents [14]. Simple screening methods to detect maintained adherence of cells are the staining of the attached cells with either crystal violet, neutral red or sulforhodamine B dyes. Crystal violet binds to proteins and DNA. When cells undergo cell death they detached from cell culture plate and the amount of crystal violet staining is reduced [15]. Indeed, some of the extracts and fractions with cytotoxic activity were able to reduce the color intensity of crystal violet, showing inhibition of cell proliferation and marked cell death at low concentrations $(<30 \mu \mathrm{g} / \mathrm{mL})$.

Primary screening of plant materials for anticancer activity with the crystal violet assay is a standard method for selecting choice pharmacological products for secondary screening to enable 
testing at range of doses [12]. The primary screening was designed to assess the threshold for cell growth inhibition produced at one concentration of extract (e.g., $50 \mu \mathrm{g} / \mathrm{mL}$ ), enabling only extracts which satisfy the threshold inhibition criteria to progress to the 5-dose screening designed to capture efficiently the compounds with antiproliferative activity in the form of $\mathrm{IC}_{50}$ values [16].

The results of primary screening revealed that the DCM and methanol extracts were cytotoxic to the cell lines at concentrations below $50 \mu \mathrm{g} / \mathrm{mL}$ and thus were subjected to secondary screening.

L. barteri hot and cold extracts and silica gel chromatography fractions showed strongest antiproliferative activity against KYSE 70, SiSo, 5673 and HepG2 cancer cell lines at very low $\mathrm{IC}_{50}$ values. The DSbEh and DSbEc gave more inhibition against all the cell lines than DLEc while the MLEc inhibited 5637 and SiSo cell lines more than the MSbEc. This activity increased with column fractionation of the extracts. There was a selective activity of extract and fractions from the stem bark for the KYSE 70 cell line more than those from the leaf, suggesting its efficacy in oesophageal squamous cell carcinoma [17].

SiSo is a human cancer cell line which was established from a patient afflicted with uterine cervical adenocarcinoma. The growth of SiSo cell line was markedly inhibited by the cold dichloromethane extracts which increased with fractionation. The DLEc and its fractions had more inhibitory effect on SiSo and high selectivity for this cell line than other extracts and fractions.

Brine shrimp lethality assay is an essential tool used for preliminary assessment of toxicity of medicinal plant products by measuring their potentials to kill larvae of Artemia salina leach [18]. It is an all-or-none method of assay. The lethal concentration $\left(\mathrm{LC}_{50}\right)$ of the DLEc that killed the $50 \%$ of the population of the larvae was higher than the concentration of DSbEc that killed the same percentage of the population. The concentration of the DLEc effective at $50 \%$ of the population $\left(\mathrm{EC}_{50}\right)$ was higher than that of DSbEc even though they had the same therapeutic index. The $\mathrm{EC}_{50}$ of a quantal dose response curve represents the concentration of a compound where $50 \%$ of the population exhibits a response after a specific exposure time. It also measures the potency of substances [19]. Therefore, the stem bark extract with lower $\mathrm{EC}_{50}$ and $\mathrm{LC}_{50}$ values was more potent as toxic agent than the leaf extract.

Assessment of the mechanism of cytotoxic activity of the most active fractions from the leaf and stem bark extracts of L. barteri revealed some level of apoptotic activity and cell cycle arrest. Apoptosis is a form of programmed cell death in multicellular organisms that involves biochemical cascade of events leading to morphological changes such as (blebbing, cell plasmolysis, nuclear fragmentation, chromatin condensation and chromosomal DNA fragmentation) and eventual death without affecting the normal cell [20]. Apoptosis can be initiated by anticancer drugs, gamma and ultraviolet irradiation, deprivation of survival factors such as interleukin-1, and several other cytokines that activate "death receptors" such as Fas and tumour necrosis factor receptors [20]. Fraction 2E had higher apoptosis induction potential than other fractions. This was evident with the greater percentage of fractions of annexin $\mathrm{V}$ positive cells than those that are positive to both annexin $\mathrm{V}$ and propidium iodide (PI). Annexin V binds to phosphatidyl serine on the extracellular surface of the cell membrane while propidium iodide binds DNA of only cells that have lost their membrane integrity. However, living cells with intact cell membrane do not stain positive to PI, and cells that are positive to Annexin V and PI are considered dead while those only positive to Annexin V are considered to be undergoing apoptosis [21,22].

The cell cycle is a physiological process that occur in distinct stages to assure controlled cell growth, development and division. Cell proliferation and differentiation are under tight genetic control in normal cells. For cancer to arise there is altered control in the genetic machinery that controls cell proliferation and eventual progression of stages of cell cycle which is the hallmark of cancer growth and sustenance [23]. Cell cycle analysis by DNA content measurement is a method that most often employs flowcytometry to distinguish cells in different phases of the cell cycle and quantification of intracellular components especially DNA, as well as cell cycle-related metabolic molecules such as cyclin-dependent kinases and cyclins [23]. The fractions showed non-specific cell cycle arrest with fraction 2E showing the greatest accumulation of DNA at G2/M phase and corresponding decrease 
in G1/G0 phase in SiSo cancer cell line. This suggests that fraction 2E may be arresting the cell cycle progression at this stage implying that DNA damage may be partly involved in the cell death.

In conclusion, our findings show that the cold DCM extracts and fractions from the Lannea barteri leaf and stem bark possess potent anticancer activity against 5637 (urinary bladder), KYSE 70 (oesophageal squamous), SiSo (cervix adeno-) and HepG2 (hepatocellular) human carcinoma cell lines. The stem bark extract showed greater activity than the leaf extract. It would appear that apoptosis and cell cycle arrest at G2/M phase are likely anticancer mechanisms of action. The anticancer activity may be attributed to unknown phytoconstituents inherent in the plant. Work is ongoing to purify the most active fraction, isolate and characterize the compound(s) that have the anticancer activity, to test them on other cancer cell lines and to explore other possible mechanism(s) of cytotoxic activity.

\section{Materials}

\subsection{Equipment and Apparatuses}

Digital and electronic weighing balance (Satorius ${ }^{\circledR}$ Entris, BP 21005, Goettigen, Germany), ultrasonicator (Bandelin Sonopuls UW 2070 ${ }^{\circledR}$, Berlin, Germany), magnetic stirrer (Heidolph models MR $^{\circledR} 3000$ and MR 3001, Schwabach, Germany), rotary evaporator (Buchi Rotavapor ${ }^{\circledR}$, R-200 and R-210, Duisburg, Germany) with heating bath (Buchi heating bath ${ }^{\circledR}$, B-490 and B-491, ), folded qualitative filter paper 301 size $185 \mathrm{~mm}$ with particle retention size of $12-15 \mu \mathrm{m}$, flasks (conical and round bottom), measuring cylinders, mechanical grinding machine, refrigerator of $-20^{\circ} \mathrm{C}$, lyophilizer, analytical TLC plates (silica gel $60 \mathrm{~F}_{254}, 20 \times 20$ ) and silica gel (Kieselgel $60 \mathrm{H}, 70-230$ mesh, Merck, Darmstadt, Germany), VLM EVA $2^{\circledR}$ Evaporator (VLM GmbH, Bielefeld, Germany), column fractions retriever, 96-well microtiter plates and $25 \mathrm{~mL}$ and $75 \mathrm{~mL}$ flasks (Sarstedt, Nümbrecht, Germany), 8- and 12- channel-pipette (Labopette 50-250 $\mu \mathrm{L}$, Hirschmann ${ }^{\circledR}$, Eberstadt, Germany), centrifuge (Heraeus Biofuge primo R) and incubator (Heracell, ThermoFisher Scientific, Waltham, M.A, USA), particle counter and size analyzer (Coulter Z2, Beckman Coulter, Fullerton, CA, USA), sterile filters (PAN ${ }^{\circledR}$ Biotech $\mathrm{GmbH}$, Aidenbach, Germany), universal shaker, (Lab Tec Edmund BühlerGmbH TiMix, Hechingen, Germany), HPLC system (Merck-Hitachi LaChrom, Fukuoka, Japan), microtiter plate reader (SPECTRAmax Plus, Molecular Devices, San Jose, CA, USA) and flow cytometer (MACS Quant Analyzer, Miltenyi Biotec, Teterow, Germany).

\subsection{Chemicals and Solvents}

All solvents were analytical grade and water was purified either by distillation or with an Elga PureLab Flex4 (Veolia Water Tech, Celle, Germany), penicillin/streptomycin solution (10,000U penicillin/mL, $10 \mathrm{mg}$ streptomycin/mL), RPMI-1640 culture medium ${ }^{\circledR}$ and L-glutamine (PAN Biotech, Aidenbach, Germany), ribonuclease-A (Rnase) and $\mathrm{NaHCO}_{3}$ (Carl Roth GmbH, Karlsruhe, Germany), $50 \%$ glutaraldehyde solution, trypsin-EDTA solution and fetal calf serum (FCS) (Sigma-Aldrich, Munich, Germany), HPLC gradient acetonitrile (ACN) (VWR International, Darmstadt, Germany), Dulbecco's buffer (pH 7.4): $\mathrm{KCl}-0.2 \mathrm{~g} / \mathrm{L}, \mathrm{NaCl}-8 \mathrm{~g} / \mathrm{L}, \mathrm{MgSO}_{4} .7 \mathrm{H}_{2} \mathrm{O}-0.1 \mathrm{~g} / \mathrm{L}, \mathrm{KH}_{2} \mathrm{PO}_{4}-0.2 \mathrm{~g} / \mathrm{mL}$, $\mathrm{Na}_{2} \mathrm{HPO}_{4} .7 \mathrm{H}_{2} \mathrm{O}-1.55 \mathrm{~g} / \mathrm{mL}$, AnnexinV apoptosis kit (Miltenyi Biotec, Teterow, Germany), propidium iodide (Applichem, Darmstadt, Germany), phosphate buffered saline (PBS), Triton X-100 (Merck, Darmstadt, Germany).

\subsection{Cancer Cell Lines}

KYSE 70, SiSo, 5673 and HepG2 human cancer cell lines were obtained from the German Collection of Microorganisms and Cell Culture (DMSZ Braunschweig, Germany).

\subsection{Brine Shrimp Larvae}

Artemia salina larvae were obtained from Department of Veterinary Pharmacology, Faculty of Veterinary Medicine, University of Nigeria, Nsukka. 


\section{Methods}

\subsection{Plant Collection and Preparation}

The fresh leaves and stem bark of Lannea barteri were collected from Benue State, Nigeria in the months of March and April by Mr. Alfred Ozioko of International Centre for Drug Discovery and Development and the specimen voucher (Voucher No: 096) deposited at the Centre's herbarium. The plant materials were dried under shade, and subsequently pulverized into powder for future use.

\subsection{Distillation of Solvents Used for Extraction and Fractionation}

All extraction solvents were distilled to their pure states according to their specific boiling points: $65^{\circ} \mathrm{C}$ (methanol), $39.8^{\circ} \mathrm{C}$ (dichloromethane (DCM)), 59 ${ }^{\circ} \mathrm{C}$ (ethyl acetate) and $69^{\circ} \mathrm{C}$ (n-hexane).

\subsection{Cold Extraction of the Plant Materials}

About $2 \mathrm{~g}$ each of the powdered material were subjected to successive cold extraction by using the following solvents in increasing order of polarity; DCM, methanol and water. The powdered material was soaked in about $100 \mathrm{~mL}$ solvent in a conical flask and then sonicated for $10 \mathrm{~min}$ in an ice pack to break the cell wall of the plant biomass. Afterwards, the flask was placed on a magnetic stirrer for $180 \mathrm{~min}$ at $250 \mathrm{rpm}$. The content of the flask was centrifuged at $3500 \mathrm{rpm}$ for $10 \mathrm{~min}$ and the supernatant filtered into a round bottom flask. The extraction process was repeated two more times after which the filtrates were pooled together and evaporated by using a vacuum rotary evaporator in a fume hood according to the boiling pressure of the solvent: $880 \mathrm{mbar}$ (DCM), $337 \mathrm{mbar}$ (methanol) and 72 mbar (water) at $50^{\circ} \mathrm{C}$. After extraction with each solvent, the marc was dried overnight in a fume hood before the next solvent was used until the last solvent. The concentrated extracts yielded cold (DCM) leaf (DLEc) and stem bark (DSbEc) extracts, cold methanol leaf (MLEc) and stem bark (MSbEc) extracts and cold water leaf (WLEc) and stem bark (WSbEc) extracts which were weighed, yield in (\%) calculated and stored in the refrigerator for future use.

The extracts were subjected to anticancer screening by the crystal violet cell proliferation assay as a bioactivity guide (see below).

\subsection{Sohxlet (hot) Extraction of the Plant Materials}

About $10 \mathrm{~g}$ of the plant material was extracted successively with these solvents in the increasing order of polarity according to their boiling temperatures $39.8^{\circ} \mathrm{C}(\mathrm{DCM}), 65^{\circ} \mathrm{C}$ (methanol), and $100^{\circ} \mathrm{C}$ (water) in continuous extraction for $12 \mathrm{~h}$ by using a Sohxlet extraction apparatus. After extraction with each solvent, the marc was dried overnight in a fume hood before the next solvent was used until the last solvent. The extracts were concentrated using rotary evaporator as described in Section 5.3 to yield hot DCM leaf (DLEh) and stem bark (DSbEh) extracts, hot methanol leaf (MLEh) and stem bark (MSbEh) extracts and hot water leaf (WLEh) and stem bark (WSbEh) extracts. These extracts were weighed, yield in (\%) calculated and stored in the refrigerator for future use.

The extracts were subjected to anticancer screening by the crystal violet cell proliferation assay as a bioactivity guide (see below).

\subsection{Thin Layer Chromatography (TLC) of the Most Active Extract}

The DSbEc and DLEc which exhibited the greatest antiproliferative activity were subjected to TLC by using 1:1 ratio of analytical grade n-hexane and ethyl acetate and the retention factors were calculated [24].

\subsection{Column Chromatography of DLEc and DSbEc with Gradient Elution Method}

The DLEc and DSbEc were subjected to column fractionation on $60 \mathrm{H} \mathrm{70-230} \mathrm{mesh} \mathrm{silica} \mathrm{gel}$ by using gradient elution method with these respective solvent combination ratios (9:1 (200 mL), 1:1 
(200 mL), 2:8 (200 mL)) of analytical grade n-hexane and ethyl acetate; and lastly 100\% methanol $(100 \mathrm{~mL})$. The resulted fractions (1A-K from DLEc and 2A-2J from DSbEc) were further subjected to primary screening with the crystal violet cell proliferation assay. The seven fractions (1E-K) from DLEc and six fractions from DSbEc (2D-I) that gave the lowest $\mathrm{T} / \mathrm{C}_{\text {corr }}$. $(\%)$ values were selected for secondary screening using crystal violet cell proliferation assay and determination of $\mathrm{IC}_{50}$. The fractions were then subjected to HPLC analysis.

\subsection{High Performance Liquid Chromatographic (HPLC) Separation}

The cytotoxic fractions $(50 \mathrm{mg} / \mathrm{mL})$ mentioned in Section 5.6 were subjected to reversed phase HPLC analysis with the following conditions: $10 \mu \mathrm{L}$ were injected onto a $250 \times 4 \mathrm{~mm}$ Nucleodur PolarTec $(5 \mu \mathrm{m})$ column (Macherey-Nagel, Dueren, Germany) held at $30^{\circ} \mathrm{C}$ and eluted with a solvent mixture containing $10 \mathrm{mM}(\mathrm{pH}=3.3)$ phosphate buffer $(\mathrm{PB})$ and acetonitrile $(\mathrm{ACN})$ at a flow rate of $0.7 \mathrm{~mL} / \mathrm{min}$ according to the following program:: - 80:20PB/ACN for $5 \mathrm{~min}$, linear gradient to 20:80 $\mathrm{PB} / \mathrm{ACN}$ over $20 \mathrm{~min}, 20: 80 \mathrm{~PB} / \mathrm{ACN}$ for $10 \mathrm{~min}$. Detection was done with a diode array UV/vis detector set to scan wavelengths between $210-600 \mathrm{~nm}$ and monitoring at $250 \mathrm{~nm}$ for a period of $35 \mathrm{~min}$.

\subsection{Phytochemical Analysis of DLEc and DSbEc}

The DLEc and DSbEc were screened for the presence of bioactive components following the methods of $[25,26]$.

\subsection{BiologicalStudies}

\subsubsection{Crystal Violet cell Proliferation Assay}

The crystal violet cell proliferation assay was used as a bioactivity guide in both primary and secondary screening assays as previously described $[27,28]$. To prepare the $96-$ well microtiter plates, the cell cultures were first treated with trypsin-EDTA to obtain a cell suspension. Then, $100 \mu \mathrm{L}$ of the cell suspensions were seeded at a density of 1000 cells per well for each cancer cell line. The plates were incubated for $24 \mathrm{~h}$ before treatment with the extract samples. Following treatment (see below), the cells were incubated $96 \mathrm{~h}$, cell growth was stopped by replacing the culture medium with $1 \%$ glutaraldehyde buffered saline (GBS) for $20 \mathrm{~min}$ and then stored under Dulbeccos's buffer solution. Later, the buffer solution was removed and the cells were stained with $0.02 \%$ crystal violet in deionized water $(100 \mu \mathrm{l}$ per well) for $30 \mathrm{~min}$. Thereafter, the excess dye was discarded and the plates washed in water for $30 \mathrm{~min}$. The cell-bound dye was re-dissolved with 70\% ethanol (100 $\mu$ l per well) and the plates were placed on the microtiter shaker for $2 \mathrm{~h}$ before the optical density (OD) was read at $\lambda=570 \mathrm{~nm}$ with a microtiter plate reader. The corrected percent growth values, e.g., Treated versus Control corrected percentage $(\mathrm{T} / \mathrm{C})$ corr. $(\%)$ was calculated with the equation:

$$
(\mathrm{T} / \mathrm{C})_{\text {corr. }}(\%)=\left(\mathrm{OD}_{\mathrm{T}}-\mathrm{OD}_{\mathrm{C}, 0}\right) /\left(\mathrm{OD}_{\mathrm{C}}-\mathrm{OD}_{\mathrm{C}, 0}\right) \times 100
$$

where $\mathrm{OD}_{\mathrm{T}}$ is the mean $\mathrm{OD}$ of the treated cells, $\mathrm{OD}_{\mathrm{C}}$ the mean $\mathrm{OD}$ of the controls, and $\mathrm{OD}_{\mathrm{C}, 0}$ the mean OD of seeded cells at the time the drug was added.

The $\mathrm{IC}_{50}$ (half maximal inhibitory concentration) values were estimated by linear least - square regression of the $(\mathrm{T} / \mathrm{C})$ corr. $(\%)$ by using $\mathrm{MS}$ Excel ${ }^{\circledR}$ function trend values versus the logarithm of the concentration of extract. The concentration that showed $(\mathrm{T} / \mathrm{C})$ corr. values between $10 \%$ and $90 \%$ were used in the calculation. The reported $\mathrm{IC}_{50}$ values are the average of 3 independent experiments. The $\mathrm{IC}_{50}$ value indicated the potency of the extract and equaled the amount of complex that inhibited the cell growth by $50 \%$. The lower the $\mathrm{IC}_{50}$ value the greater the potency of the extract. 
Primary Screening

Cells were treated with stock solution of the extracts dissolved in DMSO at $50 \mathrm{mg} / \mathrm{mL} ; \mathrm{a} 10 \mu \mathrm{L}$ of the stock solution was added to $5.0 \mathrm{~mL}$ of RPMI medium containing $10 \%$ FCS and $1 \%$ penicillin/streptomycin solution, of which $100 \mu \mathrm{L}$ of the solution was added to each well to give final concentrations of $50 \mu \mathrm{g} / \mathrm{mL}$ extract mass.. One plate was left untreated for each cell line and this served later as the control (C) at time zero $(0)(C, 0)$ when results were obtained. The plates at time zero were stopped as previously described above. Treated cells were returned to the incubator for $96 \mathrm{~h}$ at $37^{\circ} \mathrm{C}$ and stored after fixation with GBS in the refrigerator at $4^{\circ} \mathrm{C}$ until required [27]. The $\mathrm{T} / \mathrm{C}$ corr. values for the extracts were calculated as described above.

Secondary Screening

Two-fold serial dilutions of the $50 \mathrm{mg} / \mathrm{mL}$ stock solution were made by diluting with DMSO to obtain five stock dilutions. The stock solution was diluted 1:500 with the culture medium and $100 \mu \mathrm{l}$ were added to cells in 96-well plate as triplicates starting with the least concentration to the highest concentration [27]. The plates were returned to the incubator for $96 \mathrm{~h}$ at $37^{\circ} \mathrm{C}$ and the plates at time zero were stopped with glutaraldehyde fixation. After incubation period, treated cells were handled as described above and $\mathrm{IC}_{50}$ values of the extracts estimated.

\subsubsection{Brine Shrimp Toxicity Assay (BSCA)}

The toxic effect of DLEc and DSbEc on brine shrimp larvae was measured by using a previously reported method $[29,30]$.

5.9.3. Determination of Mechanism of Cytotoxic Action of Most Active Fractions on SiSo Cancer Cell Line

Fractions 1H, 1I and 2E, 2F were selected for apoptotic and cell cycle analysis with the SiSo cell line. Apoptosis Measurement

The induction of apoptosis of the fractions on SiSo cell line was determined by using an Annexin-V/propidium iodide double staining, flow cytometric method as described previously [31].

Cell Cycle Analysis: Propidium Iodide (PI) Staining

The ability of the fractions to arrest the cell cycle progression in SiSo cell line was done by staining cells with propidium iodide and measuring the phases of the cell cycle by flow cytometry as described previously [32].

A summary of the extraction, fractionation and testing procedures is shown in Scheme 1. 


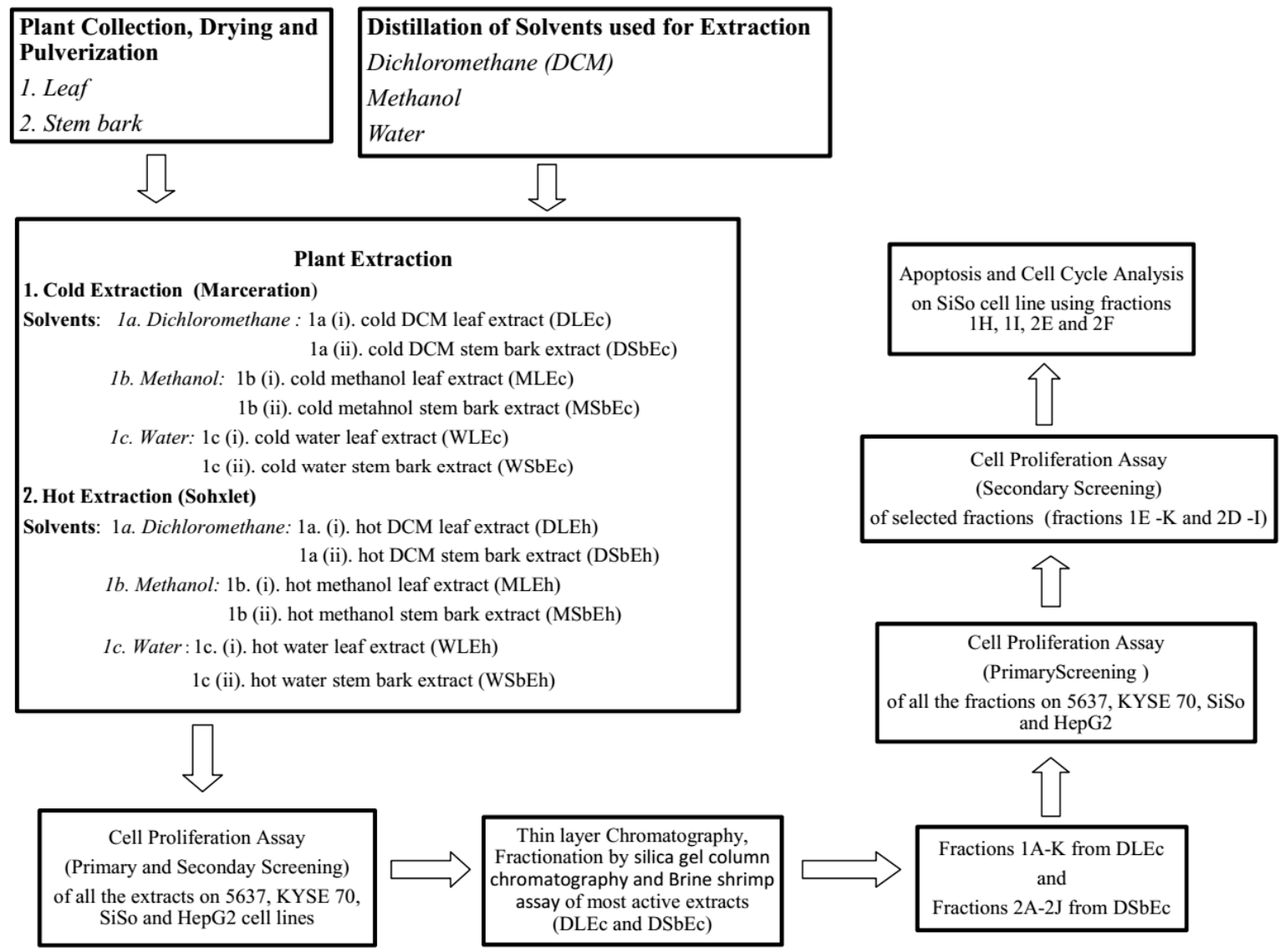

Scheme 1. Flowchart summary of the extraction, fractionation and testing procedures.

Supplementary Materials: The RP-HPLC Chromatograms of active fractions from Lannea barteri Oliv. (Anacardiaceae) cold DCM leaf (fractions1-K) and stem bark (fractions 2D-2J) extracts. (Figures S1-S13: Chromatogram of fractions 1E-1K and 2D-2I. Chrom Type: Integrated Chromatogram between wavelengths 240 to $260 \mathrm{~nm}$ respectively). DOI: 10.5277/molecule: 171819 link: https://molecule.org/record/202122.

Author Contributions: Conceptualization, F.N.M and P.J.B.; Data curation, F.N.M. and P.J.B.; Formal analysis, F.N.M. and S.B.-C.; Funding acquisition, F.N.M.; Investigation, F.N.M., S.B.-C. and P.J.B.; Methodology, F.N.M and P.J.B.; Project administration, F.N.M. and P.J.B.; Resources, P.J.B.; Supervision, A.C.E., C.S.N. and P.J.B.; Writing-original draft, F.N.M.; Writing-review \& editing, F.N.M., P.J.B., S.B.-C., A.C.E. and C.S.N. All authors have read and agreed to the published version of the manuscript.

Funding: This research was funded by Tertiary Education Trust Fund (TETFUND), Nigeria for Institutional Based Research (IBR) grant (2015) and Academic Staff Training and Development (AST\&D) scholarship (Benchwork) with number UN/VC/T19/N.5. The APC was funded by DFG German Research Foundation, 393148499) and Open Access Publication Fund of the University of Greifswald.

Acknowledgments: We are grateful to Christian Schulze, Sabine Mundt and Monika Matthias for their very helpful guidance with the extraction work. We also thank Sebastian Günther for his support. We appreciate Aruh Anaga for providing the brine shrimp eggs and Alfred Ozioko for providing the plant materials. The authors thank Tertiary Education Trust Fund (TETFUND), Nigeria for providing the funding [Institutional Based Research (IBR, 2015) grant and Academic Staff Training and Development (AST\&D), 2017 fund (Benchwork)] used in conducting the research. We acknowledge support for the Article Processing Charge from the DFG German Research Foundation, 393148499) and Open Access Publication Fund of the University of Greifswald.

Conflicts of Interest: The authors declare no conflict of interest.

\section{References}

1. Majid, A.; Mahmoud, R.; Hedayatollah, S. A systematic review of medicinal plants with anti-cancer activity. J. Cancer Sci. Ther. 2015, 7. [CrossRef] 
2. Arbonnier, M. Arbres, arbustes et lianes des zones sèchesd'Afrique de l'Ouest, 2nd ed.; (CIRAD)-MNHN: Paris, France, 2002; p. 573.

3. Blench, R.; Dendo, M. Fulfulde names for plants and trees in Nigeria, Cameroun, Chad and Niger, Latin-Fulfulde index Circulation Version. Available online: https:/www.researchgate.net/publication/ 237253671 (accessed on 28 January 2019).

4. Burkill, H.M. The useful plants of west Tropical Africa; Royal Botanic Gardens: Kew, London, UK, 1985; p. 319.

5. Lannea barteri-Useful Tropical Plants. Available online: http://tropical.theferns.info/viewtropical.php?id= Lannea+barteri (accessed on 28 January 2019).

6. Irvine, V.R. Woody plants of Ghana with special reference to their uses; Oxford University Press: London, UK, 1961; p. 868.

7. Kone, W.M.; Soro, D.; Dro, B.; Yao, K.; Kamanzi, K. Chemical composition, antioxidant, antimicrobial and acetylcholinesterase inhibitory properties of Lannea barteri (Anacardiaceae). AJBAS 2011, 5, 1516-1523.

8. $\quad$ Brice, B.J.; Benson, B.B.; Fernique, K.K.; Mida, K.G.R.; Christian, K.K.; Nathalle, G.K.; Akhanovna, M.-B.J.; Yves-alain, B. Lannea barteri Engl. (Anacardiaceae) plant used in the treatment of urinary tract infections in Ivory Coast: Biological and chemical studies of the aqueous extract. Int. J. Pharm. Pharm. Sci. 2018, 10, 64-69. [CrossRef]

9. Garba, K.; Yaro, A.; Ya'U, J. Anticonvulsant effects of ethanol stem bark extract of Lannea barteri (Anacardiaceae) in mice and chicks. J. Ethnopharmacol. 2015, 172, 227-231. [CrossRef] [PubMed]

10. Mbaoji, F.N.; Nweze, J.A. Antioxidant and hepatoprotective potentials of active fractions of Lannea barteri Oliv. (Anacardiaceae) in rat. Heliyon (under review).

11. Mbaoji, F.N.; Peter, I.E.; Onwuka, A.M. Wound healing, anti-inflammatory and antimicrobial activities of methanol leaf extract and fractions of Lannea barteri Oliv. Engl. (Anacardiaceae) in rats. Drug Discovery 2020, 14, 25-32.

12. National Cancer Institute (NCI). NCI-60 screening methodology. 2015. Available online: http://https: //dtp.cancer.gov/discovery_development/nci-60/methodology.htm (accessed on 1 October 2019).

13. López-Sáez, J.F.; De La Torre, C.; Pincheira, J.; Giménez-Martín, G. Cell proliferation and cancer. Histol. Histopathol. 1998, 13, 1197-1214. [PubMed]

14. Lage, O.M.; Ramos, M.C.; Calisto, R.; Almeida, E.; Vasconcelos, V.; Vicente, F. Current Screening Methodologies in Drug Discovery for Selected Human Diseases. Mar. Drugs 2018, 16, 279. [CrossRef] [PubMed]

15. Feoktistova, M.; Geserick, P.; Leverkus, M. crystal violet assay for determining viability of cultured cells. Cold Spring Harb. Protoc. 2016, 2016. [CrossRef] [PubMed]

16. Burger, A.M.; Fiebig, H.-H. Preclinical screening for new anticancer agents. In Handbook of anticancer pharmacokinetics and pharmacodynamics, 2nd ed.; Rudek, M.A., Chau, C.H., Figg, W.D., McLeod, H.L., Eds.; Humana press: New York, NY, USA, 2014; Volume IX, 836, pp. 145-150.

17. Shimada, Y.; Imamura, M.; Wagata, T.; Yamaguchi, N.; Tobe, T. Characterisation of 21 newly established oesophageal cancer cell lines. Cancer 1992, 69, 227-284. [CrossRef]

18. Quazi, S.S.; Fatema, A.C.; Mir, M. Brine shrimp lethality assay. Bangladesh J. Pharmacol. 2017, 12, $186-189$.

19. Definitions.net. ec50. (n.d). Definitions.net. 2019. Available online: https://www.definitions.net $\mid T 1 \backslash$ textgreater\{\}definition (accessed on 3 June 2019).

20. Renehan, A.G.; Booth, C.; Potten, C.S. What is apoptosis, and why is it important? BMJ 2001, 322, $1536-1538$. [CrossRef] [PubMed]

21. van der Mark, V.A.; Elferink, R.P.O.; Paulusma, C.C. P4 ATPases: Flippases in Health and Disease. Int. J. Mol. Sci. 2013, 14, 7897-7922. [CrossRef] [PubMed]

22. Geske, F.J.; Nelson, A.C.; Lieberman, R.; Strange, R.; Sun, T.; Gerschenson, L.E. DNA repair is activated in early stages of p53-induced apoptosis. Cell Death Differ. 2013, 7, 393-401. [CrossRef] [PubMed]

23. Olson, R.J.; Zettler, E.R.; Durand, M.D. Phytoplankton Analysis Using Flow Cytometry. Handb. Methods Aquat. Microb. Ecol. 2018, 175-186.

24. McNaught, A.D.; Wilkinson, A. IUPAC Compendium of Chemical Terminology Retention factor, $k$ in Column Chromatography, 2nd ed.; Royal Society of Chemistry: Cambridge, UK, 2006; Online corrected version: (2006).

25. Harborne, A.J. Phytochemical Methods. A Guide to Modern Techniques of Plant Analysis; Chapman and Hall, Ltd.: London, UK, 1973; pp. 49-279.

26. Trease, G.E.; Evans, W.C. Pharmacognosy, 13th ed.; Bailliere and Tindall: London, UK, 1989; pp. 176-180. 
27. Bracht, K.; Grünert, R.; Bednarski, P.J. Correlations between the activities of 19 anti-tumor agents and the intracellular glutathione concentrations in a panel of 14 human cancer cell lines: Comparisons with the National Cancer Institute data. Anti-Cancer Drugs 2006, 17, 41-51. [CrossRef] [PubMed]

28. Mothana, R.A.A.; Grünert, R.; Lindequist, U.; Bednarski, P.J. Study of the anticancer potential of Yemeni plants used in folk medicine. Die Pharmazie 2007, 62, 305-307. [PubMed]

29. Meyer, B.N.; Ferrigni, N.R.; Putnam, J.E.; Jacobsen, L.B.; Nichols, D.E.; McLaughlin, J.L. Brine shrimp: A convenient general bioassay for active plant constituents. Planta Med. 1998, 45, 31-34. [CrossRef] [PubMed]

30. Gupta, M.P.; Monge, A.; Karikas, G.A.; Lopez de Cerain, A.; Solis, P.N.; de Leon, E.; Trujillo, M.; Suarez, O.; Wilson, F.; Montenegro, G.; et al. Screening of Panamanian medicinal plants for brine shrimp toxicity, crown gall tumour inhibition, cytotoxicity and DNA interaction. IJPPR 1996, 34, $19-27$.

31. Behnisch-Cornwell, S.; Laubenstein, G.; Bednarski, P.J. Studies of the inhibitory activities of tiopronin and mercaptosuccinic acid on glutathione peroxidase and their cytotoxic and antioxidant properties. Die Pharmazie 2019, 74, 536-542. [PubMed]

32. Kang, H.K.; Joel, M.S. Assaying cell cycle status using flow cytometry. Curr. Protoc. Mol. Boil. 2015, 111, 28.6.1-28.6.111.

Sample Availability: No sample available.

(C) 2020 by the authors. Licensee MDPI, Basel, Switzerland. This article is an open access article distributed under the terms and conditions of the Creative Commons Attribution (CC BY) license (http://creativecommons.org/licenses/by/4.0/). 